Original Article

\title{
The Impact of Spirituality and Spiritually-Oriented Therapeutic Interventions on Schizophrenia Patients
}

\author{
Özge Erduran-Tekin ${ }^{1}$ \\ Tekirdağ Guidance and Research Center
}

\begin{abstract}
Schizophrenia, with its various aspects that are as yet as unexplainable and which causes those suffering from it to move away from relationships and reality, is a severe psychiatric disorder that usually deteriorates thinking and behavior from an early age. A general definition of schizophrenia has been mentioned for the purpose of this study without describing the types of schizophrenia in detail. The main axis of the study is what role spirituality may have in increasing schizophrenic patients' wellbeing, which is the last step in the model for their medical treatment. A lack of deterioration in patients' consciousness and shortterm memory is very important in order for them to be able to understand the therapeutic practices; the study discusses spiritual counseling practices that can be studied with schizophrenic patients who have no problems in these areas. The study evaluates the concept of insight in schizophrenia patients from different perspectives and includes spiritual counseling practices that can be done with schizophrenia patients possessing high levels of insight. The study continues by examining which individual spiritual counseling practices are possible for patients with schizophrenia and presents the example of group counseling over spiritual counseling practices for patients with schizophrenia as well as which counseling practices can be done for schizophrenic patients and their families. The main aim of this study is to present to clinicians, psychologists, and psychological counselors working in the field a general review of the literature on studies that have examined the relationship between schizophrenia and spirituality and to give them ideas into how to integrate spiritual counseling practices into the process while working with schizophrenia patients and their relatives.
\end{abstract}

\section{Keywords}

Schizophrenia $\bullet$ Spiritual counseling $\bullet$ Schizophrenia and family $\bullet$ Schizophrenia and psychological support $\bullet$ Individual therapy techniques for schizophrenics

\section{Maneviyatın ve Manevi Yönelimli Terapötik Müdahalelerin Şizofreni Hastaları Üzerindeki Etkisi}

$\ddot{O} z$

Şizofreni çeşitli yönleri hala tam olarak açıklanamayan, hastanın insanlarla olan ilişkilerden ve gerçeklerden uzaklaşmasına neden olan, genelde erken yaşlardan itibaren düşünce ve davranışlarda bozulmaların görüldüğü ağır bir psikiyatrik rahatsızlıktır. Çalışmanın amacı doğrultusunda genel bir şizofreni tanımından bahsedilmiş olup şizofreni türleri detaylı olarak açıklanmamıştır. Şizofreni hastalarına yönelik tıbbi tedavi modelinin son basamağı olan iyilik halinin arttırılmasında maneviyatın rolünün ne olabileceği çalışmanın ana eksenini oluşturmaktadır. Hastaların bilinç ve kısa süreli belleklerinde bozulma olmaması terapötik uygulamaları anlamlandırabilmeleri açısından oldukça önemli olup, bahsedilen alanlarda sorun yaşamayan şizofreni hastalarıyla çalışılabilecek olan manevi danışmanlık uygulamaları konu edinilmiştir. Şizofreni hastalarında iç görü kavramı farklı açılardan ele alınarak, iç görü düzeyi yüksek olan şizofreni hastalarıyla yapılabilecek olan manevi danışmanlık uygulamalarına yer verilmiştir. Çalışma şizofreni hastalarına yönelik bireysel manevi danışmanlık uygulamalarının neler olacağını konu alarak devam etmiş olup, çalışmada şizofreni hastalarına yönelik yapılan manevi danışmanlık uygulamalarını konu edinen grupla danışma örneği ve şizofreni hastaları ile ailelerine yönelik danışmanlık uygulamalarının neler olabileceği sunulmuştur. Çalışmanın temel amacı alanda çalışan klinisyen, psikolog ve psikolojik danışmanlara şizofreni ve maneviyat ilişkisini inceleyen çalışmalar hakkında literatür taraması sonucunda genel bir derleme sunmak olup, şizofreni hastaları ve yakınlarıyla çalışırken manevi danışmanlık uygulamalarını sürece nasıl entegre edebilecekleri hakkında fikir vermektir.

\section{Anahtar Kelimeler}

Şizofreni • manevi danışmanlık • şizofreni ve aile • şizofreni ve psikolojik destek • şizofrenide bireysel terapi teknikleri.

1 Correspondence to: Özge Erduran-Tekin (Counseling Specialist). Tekirdağ Guidance and Research Center. Hürriyet Mah. Ögretmenler Cad. No: 22/8, 59100 Süleymanpaşa/Tekirdağ TURKEY, E-mail: pskdanozgeerduran@gmail.com

Citation: Erduran-Tekin, Ö. (2019). The impact of spirituality and spiritually-oriented therapeutic interventions on schizophrenia patients. Spiritual Psychology and Counseling, 4, 309-320. http://dx.doi.org/10.37898/spc.2019.4.3.064 


\section{Schizophrenia and Its Treatment}

Schizophrenia, which usually starts at an early age, leads to a lack of competence and a dislocation from interpersonal human relations and reality; it is a severe disorder in which significant deficiencies occur in thinking and behavior. The definitions Hughlings Jackson first identified for the positive and negative symptoms of certain neurological syndromes are also frequently used for schizophrenia (Berrios, 1985). The positive symptoms are those that appear as redundancies, extremes and deviations that exceed normal. Negative symptoms are a decrease in normal functions, deficiencies, and deprivations (Öztürk \& Uluşahin, 2008). Hospitalization in schizophrenia is often necessary for patients who pose a serious threat to themselves or others, who are unable to care for themselves, or who are under the influence of delusions/hallucinations (Lehman et al., 2004). No easy or standard treatment exists for schizophrenia. A multilateral approach is essentially required, as well as being aware that every schizophrenic patient can have different individual characteristics. One of the most important steps in non-medicinal treatment is initiating psychosocial interventions and increasing well-being. A three-step plan for enhancing well-being is recommended: psychosocial training; internal vision-oriented sessions, and shared sessions oriented around decision making (Alptekin et al., 2014).

The main axis of this study is how to increase schizophrenic patients' well-being as well as how spirituality can be used on this point. While working with schizophrenic patients, their level of insight is very important; studies have shown schizophrenics' level of insight to be quite low, as in other psychotic disorders. However, insight is generally not a one-dimensional concept. It has biological, psychological, and cultural bases. Therefore, evaluating the concept of insight from the perspective that it exists or doesn't exist is insufficient. Cognitive and behavioral therapies developed for delusions and hallucinations in recent years may also be very determinative in regard to a patient's insight (Aslan \& Altınöz, 2010).

Psychotherapy is not just an option but a complement to drugs in treating schizophrenia; it should address the humanitarian problems that are generally expected to occur in a disease such as schizophrenia. Psychotherapy should be easy to apply, teach the individual methods for coping with problems through its educational aspects, ensure that patients determine their limits, and enable them to accept and cope with the results of their behavior (Coursey, 1989). On one hand, patients generally avoid establishing relationships with other people and want to live in a world of their own. On the other hand, they feel the need to deeply connect with people. In such an ongoing dilemma, the patient must be able to lean on a reliable and consistent person or persons. Therefore, psychotherapeutic approaches have a significant aspect for treating schizophrenia (McGill \& Lee, 1986). 
When considering the literature, psychoanalytically- and existentially-oriented approaches have been found to have important contributions in psychological counseling and psychotherapy with schizophrenia patients; however, a strict application of these theories' rules may lead to breaking the relationship in a short time and may even result in damage. The patient may become more introverted or dissipated. Recent studies have shown that cognitive behavioral approaches can be effectively applied in patients with schizophrenia. The main points highlighted in a study of schizophrenia patients using a cognitive behavioral approach (Turkington, Kingdon, \& Weiden, 2006) are: to establish a good relationship with the patient, to offer suggestions beyond the medical model for having patients use their medicine regularly, to explain the symptoms of schizophrenia, to show the patient alternative options for thinking, to have the patient accept the disease, and to reduce the effects of positive and negative symptoms on the patient by suggesting options for changing patients' perspectives toward these symptoms. Based on all this information, the process of a spiritual psychotherapy that is adjusted according to the individual condition of the patient is thought to be an appropriate therapy method that can be used eclectically when necessary. Supporting patients, guiding them through the process, being explanatory, giving insights into the symptoms of the disease, and providing a long-lasting healthy relationship will make a significant contribution to increasing patients' well-being.

\section{The Relationship between Schizophrenia and Spirituality}

Schizophrenia is a psychiatric disorder characterized by delusions and hallucinations, as well as deteriorations in individual and interpersonal relationships. Distinguishing between pathological and non-pathological beliefs and understanding how these beliefs affect the patient's disease are very important for clinicians in their clinical practice. The topics of this study are the non-pathological elements of spirituality which the psychiatric literature does not define as delusional but of which the patients are conscious and use as a method for coping. Schizophrenic patients usually have consciousness and orientation. In some types of schizophrenia, patients may have a high degree of indifference and callousness, and may occasionally respond wrongly to the questions they are asked. Usually the presence of a disorder in consciousness and orientation can be determined through ongoing observations and by helping the patient gather their attention in different ways (Öztürk \& Uluşahin, 2008). Studies show short-term memory to be the most important factor predicting the addition of new knowledge and skills to a patient's memory using any therapeutic technique (Mueser \& Berenhaum, 1990). Therefore, psychotherapy and psychoanalytic counseling can be done with schizophrenic patients who have no major disorder in consciousness or orientation. Psychotherapy and psychoanalytic counseling as psychosocial treatments can be organized according to their focus and 
locus, and the focus of psychosocial treatment can be on the individual in a group setting, the family setting, or a total milieu setting (Liberman, 1994).

Spirituality, psychotherapy, and schizophrenia are frequently discussed in the literature. Researchers and psychotherapists have historically doubted the suitability of the use of spiritual and religious resources in psychotherapy and have questioned the application of psychotherapy for schizophrenia. When considering studies overall, Phillips and Stein (2007), while researching young adults suffering from mental illnesses, found these patients to generally use the same coping strategies with healthy individuals. In another study, Pergament, Koenig, and Perez (2000) found benevolent religious evaluation to have positive effects on mental health and the idea of a punitive God or thinking about God's power to lead to more negative mental-health effects. In a long-term study (Mohr et al., 2010), chronic schizophrenic patients showed how spirituality varies over time and that these changes are associated with decreased self-esteem and quality of life. Studies have found patients with religious delusions to have higher symptom scores and less activity than other psychotic patients. After medically treating the disease, many people diagnosed with schizophrenia reported having increased faith, seeking religious coping and spiritual guidance to manage the symptoms of the disease, and remaining connected to authentic bonds with God to have been beneficial even though they had been diagnosed with the disease (Lukoff, 2007). Religious and spiritual practices such as acceptance and forgiveness, prayer, meditation, and worship are coping areas that have been developed in the context of psychotherapy that can positively improve the ways people deal with adversity, especially people with schizophrenia (Mizock, Millner, \& Russinova, 2012).

Many people with schizophrenia do not disclose their religious or spiritual beliefs because they fear being deliberately labeled and inadvertently hospitalized (Huguelet, Mohr, Borras, Gillieron, \& Brandt, 2006). In this context, one of the ways that patients can receive counseling after the necessary medical intervention is through spiritual counseling. As a result of a study conducted using semi-structured interviews to measure the coping skills of 50 patients diagnosed with schizophrenia, Özcan, Gürgen, and Türkeş (1999) found $85 \%$ of the respondents to have used religious activities as a way of coping. Patients with schizophrenia who use positive religious coping methods require less hospitalization and have less severe symptoms (Tepper, Rogers, Coleman, \& Maloney, 2001). As a result of one study conducted with 346 schizophrenic patients being treated in inpatient psychiatric wards and community mental health centers in Kocaeli and Sakarya, $89 \%$ of the participants had applied to religious staff for help at least once in their lifetime (Yazic1 et al., 2016).

The close relationship among spirituality, the meaning-making process, and psychosis is certainly different from what quantitative research has found. Namely, 
religiousness is broad enough not to be associated with psychopathology (Huguelet et al., 2006). Belief can sometimes increase relief, optimism, flexibility, social support, hope, positive identity, and insight, as well as help with a positive sense of self during delusions. These results indicate the potential benefits of integrating spiritual and religious content into therapy with schizophrenia patients (Miller \& Mc Cormack, 2006). However, other studies exist that have pointed to the negative effects of religion and spirituality on mental health (Borras et al., 2007; Siddle, Haddock, Tarrier, \& Faragher, 2002). While suffering, spirituality can become damaged because seeing God as a compassionate and omnipotent being becomes difficult (Trevino \& Pargament, 2008).

\section{Spiritually-Focused Counseling and Individual Counseling for Patients with Schizophrenia}

When treating schizophrenia, the concept of hope can be considered foremost in the content of spiritual counseling practices. Hope is an essential component in healing and providing positive coping skills for mental illnesses such as schizophrenia. Hope can be said to be at the center of the concept of recovery from mental disorders because it is both a trigger in the healing process as well as a sustaining factor (Schrank, Stanghellini, \& Slade, 2008).

Lyu and Zhang (2014) reported in their study that schizophrenic patients with low levels of hope attempt suicide more often. Vrbova et al. (2017), in a crosssectional study of schizophrenic patients, showed hope to be one of the determinants of patients' quality of life. Olçun and Şahin Altun's (2017) study found high hope in schizophrenic patients to decrease the level of internalized stigma and increase resistance to stigmatization. Hope is seen in the Jewish-Christian tradition as a virtue of God and a spiritual gift (Schrank, Hayward, Stanghellini, \& Davidson, 2011). From the Islamic point of view, God, who creates disease, also creates healing. One must trust Allah and be free from the feelings of vulnerability and despair; after doing everything necessary for the treatment of a disease, one must believe that the high power is on their side. This is called tawakkul in the Islamic literature, which means to rely on and trust in God. This is clearly stated in the Qur'an (65:3), "And will provide for him from where he does not expect. And whoever relies upon Allah - then $\mathrm{He}$ is sufficient for him. Indeed, Allah will accomplish His purpose. Allah has already set for everything a [decreed] extent." Hopefulness and reliance in schizophrenic patients is considered to increase their coping skills and accelerate treatment and the healing process. For this reason, having the whole team of health specialists take steps to increase hope is of great importance.

The results from the review study conducted by Olçun and Şahin Altun (2017) recommend that people, especially nurses, should pay attention to certain behaviors 
while working with patients with schizophrenia. The relationship between health professionals and patients has a significant impact on increasing hope. When developing a therapeutic relationship with patients, accepting them and understanding their points of view are necessary. The responsibility of nurses and health workers is to provide structured trainings to improve society's level of knowledge regarding mental illnesses and reduce society's negative attitudes towards patients (Kirkpatrick, 1995). All in all, these presented behavioral recommendations are considered important for psychologists and psychological counselors working in the field.

Mizock, Millner, and Russinova's (2012) study, which examined the cultural/ religious psychotherapy practices and cultural differences of schizophrenic patients, reviewed one example of this spiritually-oriented psychological counseling framework. The steps in this consultation process include training, disquisition, evaluation, and practice. While working with a spiritual focus, therapists cannot follow this process linearly due to the nature of spiritual methods and are able to be flexible. The training phase includes the religious and spiritual development of the therapist who will provide counseling. A lack of adequate knowledge and skills in the therapist who is to provide spiritual counseling is very significant as it may result in the client being misled. In the disquisition stage, the therapist can actively question the role of spirituality in the client's life. In the evaluation stage, therapists can use measurement tools to determine the patient's level of hope to assist in this process. During the practice phase and in accordance with the spiritual history of the counselee and the goals determined in the therapy session, activities can be done such as praying; meditating; holy book or devotional readings; performing religious services in a house of worship; singing in religious groups; or talking with religious leaders, peers or providers, depending on the specific religious doctrine adhered to (Fallot, 2008). Although fundamentally a coping mechanism, religion and spirituality can help to deal not only with illnesses (symptoms) but also with challenges in social and daily life (Huguelet, Mohr, \& Borras, 2009). When reviewing published studies documenting the relationship between religion and spirituality in mental illnesses, especially in schizophrenia, depression, and substance dependence, some interventions are noticed to have been considered within the scope of spiritual counseling practices. With regard to these interventions in general, cognitive behavioral therapy, which is used to describe and alter patients' religious beliefs and unnecessary thoughts and behaviors, has been integrated into spiritual counseling to reduce symptoms of depression. Other psychological approaches to intervention are inspirational stories and citations from Jewish religious literature and spiritual assessments from a psychiatrist followed by psychologically-integrated treatment, including guidance and counseling from a religious psychologist (for schizophrenic patients). Some studies have used spiritually-oriented interventions based on the Buddhist framework, while others have found spiritual counseling practices through 
intervention groups composed of interactions between the church community and local activists (Zagozd \& Wrotkowska, 2017).

A study conducted by Rashid, Copello, and Birchwood (2012) examined which kinds of assistance the Muslim population living in the UK have sought from religious officials for psychiatric and related problems. The aim was to examine what patients told Muslim religious officials and what suggestions these officials made to the patients. For this, interviews occurred with the Muslim religious officials. As a result of the interviews, religious officials were seen to make certain suggestions to the patients and believed that these would protect the patient. When we look at the recommendations religious officials made to the patients; they concern when voices come, and the recommendations are to always to chant the name of Allah, to read the verses from Allah that will give them the confidence and power to resist the voices. To chant (preform dhikr) is a state of remembering Allah and is believed to give power in reducing and coping with the individual's psychotic symptoms. In addition to praying and reading the Qur'an, they stated giving various prayers to the patients who had for their help and showed that these patients had made progress by using them as coping methods.

When examining studies in general, although having religious-oriented skills is not necessary, having the necessary religious tools is considered to be more ethical in order to prevent the clinicians who work with schizophrenic patients from misinforming them while using spiritual methods as a means of coping.

\section{Spiritually-Focused Psychological Group Counseling in Treating Schizophrenia}

Schizophrenic patients inevitably to have great problems in human relations due to the nature of the disease. These patients are afraid of communicating with people and are also uncomfortable with their loneliness and isolation. Continuous individual therapy provides great support for establishing and maintaining a healthy relationship with patients. One of the most important problems experienced by patients is accepting the disease and not getting over the idea of why they have it. Participating in group counseling is very important for schizophrenic patients to overcome loneliness, to see that they are not the only ones that have this disease, and to learn other patients' coping strategies.

The Spirituality Matters Group (SMG) was founded in 2001 in the Clinical Research Evaluation Facility (CREF) of the Nathan Kline Institute for Psychiatric Research (NKI), which works with the Rockland Psychiatric Center (RPC). When examining SMG, it is seen to contain cognitive elements. Reading texts that are written for use in counseling sessions, presentations, and banners to create an environment of discussion can be prepared every week. Overall, each session has three stages. The 
first session establishes the necessary therapeutic relationship. The second session continues with a previously-planned group activity. This could be an activity that includes personal sharing (e.g., talking about loneliness, hope, forgiveness, patience, etc.) or reading religious stories, interpreting verses and hadiths in the therapeutic environment, creating prayers, and writing. In the final session, group members are asked to summarize the day. Then a closure is made with a formal prayer created by the group members. When examining the results obtained from the group participants, the patients who participated in the spiritually-focused counseling sessions are seen to have higher levels of hope. Spiritually-oriented group counseling practices are appropriate for cooperation. If necessary, support and guidance from religious occupational groups can be received for guiding and informing the patients. One longitudinal analysis of such interventions may be consulted to determine how mental coping and hope affect recovery in schizophrenic patients (Reyheim, Greenberg, \& Citrome, 2010).

Based on this information, clinicians who use spiritually-oriented coping methods can be said to be able to work with patients in accordance with their own competencies; by integrating spiritual counseling practices into psychological group counseling programs, they can ensure that patients positively benefit from the group consultation process while at the same time not ignoring spiritual coping methods.

\section{Spiritually-Focused Family Counseling in Treating Schizophrenia}

When considering schizophrenia in general, it is seen to occur in youths. Therefore, family members are most aware of the onset and symptoms of the disease. Especially in Turkey, where families are concerned about family ties and what other people think about them, families may try to hide their ill relatives and avoid hospitalizing them. They may feel guilty or cause the patient to feel guilty. In general, most patients live with the family, apart from short-term hospital care, and therefore the family plays an important role in patient care. In this case, informing the clinician about the patient's condition and course of the disease is family members' duty. For these reasons, dealing with the family and providing them with the necessary counseling services are important in treating schizophrenia.

Weisman de Mamani, Tuchman, and Duarte's (2010) study examined whether religion and spirituality should be included in treatments for patients with serious mental illness among ethnic minority groups living in the USA, considering that a need exists for this. Family-oriented culturally-informed therapy (CIT-S) was created by adapting existing family-oriented therapies to help schizophrenic patients make sense of negative situations and provide the social support they need. The treatment consists of five modules, each consisting of three sessions. The modules are: family collectivism, psycho-education, spiritual coping, communication education, and 
problem solving. First, the spiritual-coping module is introduced to family members in detail. Then the spiritual recollections of family members are taken in detail to find out what religious and spiritual dealings each family member has had, how often, and how they use them, as well as what they expect from religion and spirituality. Evaluating religious delusions has great importance as the distinctions among the mechanisms for coping with people's delusions is important for diagnosis. Therefore, the severity of religious-based delusions is officially assessed at each assessment point of the CIT-S. A paper is prepared for each session to ensure that the consultation session is structured. In the papers, family members are encouraged to discuss their beliefs, their perception of God, the concept of morality, and the meaning or purpose they attribute to life.

After learning the family members' spiritual and religious ways of coping, the counselor prepares spiritual columns titled Forgiveness, Empathy, Appreciation, and Peace. These are the concepts that patients and their family members often define as important principles in their lives. Likewise, family members may be asked to prepare a discussion in the next session by providing them with verses, hadiths, stories, and prayers. Finally, family members are encouraged to participate in spiritual practices that are considered meaningful and therapeutic (e.g., participation in houses of worship, prayers, holy readings; Weisman de Mamani, Tuchman, \& Duarte, 2010).

Treating diseases with an approach that does not involve the family is not possible, considering that one of the most important sources of social support is family. When we approach this issue from the point of view of geography and the cultural values Turkey has, one of the requirements that Islamic siblinghood has mutually imposed on individuals is to visit a relative who is ill. To visit a person who is ill is important in terms of supporting the morale of the patient, as well as the divine reward to be earned in return (Bedri, 1984). Therefore, family and social support have a very important place in the treatment of people's diseases.

\section{Discussion}

This study has investigated how schizophrenic patients use spirituality as a coping method and has examined what is being done in spirituality-oriented counseling practices for clinicians, psychologists, and psychological counselors. According to the results, the use of spiritually-oriented approaches in treating schizophrenic patients has been observed as a topic discussed in the literature. As with schizophrenic patients who consider religious and spiritual methods in order to cope with their disease, schizophrenic patients are also found who state that religious and spiritual orientations make the disease process difficult, that their connection with God breaks down, and that these beliefs cause damage (Pergament, Koenig, \& Perez, 2000; 
Siddle et al., 2007; Trevino \& Pargament, 2008). On this point, first distinguishing whether the patients have religious and spiritual delusions or if they have spiritual and religious beliefs that they use as coping methods is considered very important for the treatment and consultation. Non-pathological beliefs can empower the patient (Hueguelet et al., 2006).

Another important point is that in order to use spiritual counseling practices effectively, no deterioration in consciousness, memory, or orientation of the patient should be present with respect to the type of schizophrenia and its course; the patient should have a certain amount of insight (Mueser \& Berenhaum, 1990; Öztürk \& Uluşahin, 2008). Here, the main concern is that schizophrenic patients who suffer from problems in their relationships and who desire healthy relationships need to establish an effective therapeutic relationship with the therapists through the support of the therapists. After taking a detailed history of the patient's spiritual orientation, including spiritual and religious orientations in the therapy is considered appropriate if the patient uses spiritual and religious orientations as a coping method in accordance with the therapist's qualifications. Ignoring the method of coping with the disease that the patient brings to the therapy will not positively benefit the patient unless it is believed to be delusional. The aim here is not to present the therapist's religious and spiritual orientations, but to recognize those of the patient and to discuss them in the therapy environment for the patient's benefit.

In general, spiritually-oriented studies towards schizophrenia patients are seen insufficient in Turkey. However, if the patient's recollections are appropriate for psychotherapy and counseling services to support the medical treatment, an eclectic approach can be taken by integrating spiritual counseling practices. At the same time, using spiritual and religious elements while using family-oriented approaches enables acceptance of the disease process and increases cooperation with family members.

When examining the studies, techniques and structured sessions are seen to have been presented for use in individual-, group-, and family-oriented counseling approaches with schizophrenia patients (Weisman de Mamani, Tuchman, \& Duarte, 2010; Rashid, Copello, \& Birchwood, 2012). Psychiatrists who work with schizophrenic patients in clinical settings and counselors with schizophrenia patients can support patients who have spiritual readiness and can benefit from this approach by using these practices. In light of all this information, increasing studies that examine the relationship between schizophrenia and spirituality is considered very important for developing new counseling programs and avoiding misdirecting patients. 


\section{Reference}

Alptekin, K., Üçok, A., Ayer, A., Ünal, A., Erol, A., Ensari, H., Atmaca, M., Devrimci Özgüven, H. (2014). Psikiyatri kliniğine yatırılan şizofreni ve psikotik bozukluğu olan hastaların tedavi rehberi. Klinik Psikofarmakoloji Bülteni, 24(3), 276-288.

Aslan, S., Altınöz, A.E. (2010). İç görü kavramı ve şizofreni. Psikiyatride Derlemeler, Olgular ve Varsayımlar, 7, 23-36.

Bedri, M. B. (1984). Müslüman psikologların çıkmazı (Çev. Harun Şencan). İstanbul: İnsan Yayınları.

Berrios, G. E. (1985). Positive and negative symptoms and Jackson: A conceptual history. Arch Gen Psychiatry. 42(1), 95-97.

Borras, L., Mohr, S., Brandt, P., Gillieron, C., Eytan, A., Huguelet, P. (2007). Religious beliefs in schizophrenia: Their relevance for adherence to treatment. Schizophrenia Bulletin, 33, 1238 1246.

Coursey, R.D. (1989). Psychotherapy with persons suffering from schizophrenia. Schizophr Bull, 15(3), 349-353.

Fallot, R. D. (2008). Spirituality and religion. In K. T. Mueser \& D. V. Jeste (Eds.), Clinical handbook of schizophrenia (p. 592-603). The Guilford Press.

Huguelet, P., Mohr, S., Borras, L., Gillieron, C., Brandt, P. (2006). Spirituality and religious practices among outpatients with schizophrenia and their clinicians. Psychiatr. Serv. 57(3), 366-372.

Huguelet, P., Mohr S., Borras, L. (2009). Recovery, spirituality and religiousness in schizophrenia. Clinical Schizophrenia \& Related Psychoses, 2(4), 307-316.

Kirkpatrick, H., Landeen, J., Byrne, C., Woodside, H., Pawlick, J., Bernardo, A. (1995). Hope and schizophrenia: clinicians identify hopeinstilling strategies. Journal of Psychosocial Nursing and Mental Health Services, 33(6), 15-19.

Lehman, A.F., Lieberman, J.A., Dixon, L.B., McGlashan, T.H., Miller, A.L., Perkins, D.O., Kreyenbuhl, J. (2004). Practice guideline for the treatment of patients with schizophrenia, Second edition. American Psychiatric Association; Steering Committee on Practice Guidelines. Am J. Psychiatry, 161(2), 1-56.

Liberman, R. P. (1994). Psychosocial treatments for schizophrenia. Psychiatry, 57(2), 104-114.

Lukoff, D. (2007). Spirituality in the recovery from persistent mental disorders. South. Med. Assoc., 100, 642-646.

Lyu, J., Zhang, J. (2014). Characteristics of schizophrenia suicides compared with suicides by other diagnosed psychiatric disorders and those without a psychiatric disorder. Schizophrenia Research, 155(1), 59-65.

Mc Gill, C.W., Lee, E. (1986). Family psycho-educational intervention in the treatment of schizophrenia. Bulletin of the Menninger Clinic, 50, 269-287.

Mizock, L., Millner, U. C., Russinova, Z. (2012). Spiritual and Religious Issues in Psychotherapy with Schizophrenia: Cultural Implications and Implementation. Religions, 3, 82-98.

Miller, R., McCormack, J. (2006). Faith and religious delusions in first episode schizophrenia. Social Work in Mental Health, 4(4), 37-50.

Mohr, S., Borras, L., Rieben, I., Betrisey, C., Gillieron, C., Brandt, P.-Y., Huguelet, P. (2010). Evolution of spirituality and religiousness in chronic schizophrenia or schizo-affective disorders: A 3-years follow-up study. Social Psychiatry \& Psychiatric Epidemiology, 45, 1095-1103. 
Mueser, K.T., Berenhaum, H. (1990). Psychodynamic treatment of schizophrenia-is there a future? Psychol. Med., 20(2), 253-262.

Olçun, Z., Şahin Altun, Ö. (2017). The correlation between schizophrenic patients' level of internalized stigma and their level of hope. Archives of Psychiatric Nursing, 31(4), 332-337.

Özcan, M. E., Gürgen, F., Türkeş, C. (1999). Şizofrenili hastalarda başa çıkma davranışları. Düşünen Adam, 12(3), 35-40.

Öztürk, O., Uluşahin, A. (2008). Ruh sağlı̆̆ ve bozuklukları. (11. Bask1). Ankara.

Pargament, K. I., Koenig, H. G., Perez, L. M. (2000). The many methods of religious coping: Development and initial validation of the RCOPE. Journal of Clinical Psychology, 56(4), 519-543.

Phillips, R. E., Stein, C. H. (2007). God's will, God's punishment, or God's limitations? Religious coping strategies reported by young adults living with serious mental illness. Journal of Clinical Psychology, 63(6), 529-540.

Rashid, S., Copello, A., Birchwood, M. (2012). Muslim faith healers' views on substance misuse and psychosis. Mental Health. Religion \& Culture, 15(6), 653-673.

Reyheim, N., Greenberg, W. M., Citrome, L. (2010). Spirituality, Schizophrenia, and State Hospitals: Program Description and Characteristics of Self-Selected Attendees of a Spirituality Therapeutic Group. Psychiatr Q, 81, 285-292.

Schrank, B., Stanghellini, G., Slade, M. (2008). Hope in psychiatry: a review of the literature. Acta Psychiatrica Scandinavica, 118(6), 421-433.

Schrank, B., Hayward, M., Stanghellini, G., Davidson, L. (2011). Hope in psychiatry. Advances in Psychiatric Treatment, 17(3), 227-235.

Siddle, R., Haddock, G., Tarrier, N., Faragher, E. B. (2002). Religious delusions in patients admitted to hospital with schizophrenia. Social Psychiatry \& Psychiatric Epidemiology, 37, 130-138.

Şahin Altun, Ö., Olçun, Z. (2018). Şizofreni hastalığında umut kavramı. Sağhlk Bilimleri ve Meslekleri Dergisi, 5(1), 107-112.

Tepper, L., Rogers, S.A., Coleman, E.M., Malony, H.N. (2001). The prevalence of religious coping among persons with persistent mental illness. Psychiatr. Serv., 52, 660-665.

Trevino, K. M., Pargament, K. I. (2008). Toward a theoretical model of spirituality for clinical practice: An American perspective. Journal für Psychologie, 16, 1-27.

Turkington, D., Kingdon, D., Weiden, P.J. (2006). Cognitive behavior therapy for schizophrenia. Am J. Psychiatry, 163(3), 365-373.

Vrbova, K., Prasko, J., Ociskova, M., Kamaradova, D., Marackova, M., Holubova, M. (2017). Quality of life, self-stigma, and hope in schizophrenia spectrum disorders: a crosssectional study. Neuropsychiatric Disease and Treatment, 13(1), 567-575.

Weisman de Mamani, A., Tuchman, N., Duarte, E. A. (2010). Incorporating religion/spirituality into treatment for serious mental illness. Cognitive and Behaviora, 17, 348-357.

Yazıcı, E., Yazıc1, A.B., İnce, M., Erol, A., Erdoğan,A., İkiz, H.S., Kırpınar, İ. (2016). The search for traditional religious treatment amongst schizophrenic patients: the current situation. Anatolian Journal of Psychiatry, 17(3), 174-180.

Zagozd, P., Wrotkowska, M. (2017). Religious Beliefs and Their Relevance for Treatment Adherence in Mental Illness: A Review. Religions, 8, 150.

www.kuranikerim.com/mdiyanet/talak.htm 